\title{
THE ROLE OF POP MUSIC AND OTHER PHENOMENA OF MODERN CULTURE IN THE PRESERVATION OF KOMI LANGUAGE
}

\author{
Nikolay Kuznetsov
}

\begin{abstract}
The article examines the influence of pop music and other phenomena of mass culture on the preservation of Komi language in the Komi Republic, Russia in the last decade. For the majority of young people, Komi language is not prestigious; it is insufficiently represented in publishing, television and radio broadcasting, cinematography, showbusiness, virtual space, etc. These "elements of progress" (Bazhenova 2004) personify for the youth progress and prestige and should be Komified. Today it is necessary to introduce the application of Komi language more actively in the sphere of modern technologies as one of the "elements of progress". The Komi need to stop viewing their culture and language as second-rate, underdeveloped in relation to Russian culture and language. The article also discusses the activities targeted at expanding the spheres of use of the Komi language, the state support to the modern Komi culture, the influence of the phenomena of modern culture on the prestige of the Komi language, and other issues.
\end{abstract}

Key words: Finno-Ugric languages, Komi, Komi culture, Komi language, Komi music, preservation of language

The Komi (formerly Komi-Zyrians) live in the Komi Republic, Murmansk Oblast, on the Kola Peninsula, Yamalo-Nenets Autonomous Okrug in Russia and elsewhere in Siberia. The Komi language, also known as Zyrian, or Komi-Zyrian, is one of the two languages in the Permic subgroup of the Finno-Ugric branch. The other Permic language is Udmurt, to which the Komi language is closely related.

The Komi Republic (total area 415,900 sq km, capital city Syktyvkar) is a federal subject of Russia, located to the west of the Ural Mountains, in the northeast region of the East European Plain. Forests cover over 70 per cent of the territory of the republic and swamps cover approximately 15 per cent. The major industries of the Komi Republic are oil processing, timber, forest management, gas, coal, and electric power industries. The Komi Republic is perceived as a backward area because it serves only as a source of raw materials. Large interstate prison camps besmirch the reputation of the Komi region. 
According to the 2002 census, ethnic Russians make up 59.6 per cent of the republic's population (1,018,700), while the ethnic Komi constitute only 25.2 per cent. The number of the Komis in Russia is 293,400. 71 per cent of them recognise the Komi language as their mother tongue, while 28.9 per cent speak Russian. The population of the Komi Republic has tripled since the Second World War due to immigration. This means that the Komi have become a minority in their native territory.

In the article I will observe the degree to which the phenomena of modern culture, which are considered prestigious by youth, are manifest in the Komi language. Also, I will compare the attitudes of youth to their mother tongue and to the dominating state language (Russian) and discuss the expanding of the spheres of use of the Komi language and the possible influence of the phenomena of modern culture on the use of the native language among Komi youth.

\section{"YOUTH IS OUR FUTURE"}

The central theme and title of the 4th World Congress of Finno-Ugric Peoples (held on 15-19 August, 2004 in Tallinn, Estonia) was "Youth is Our Future". Unfortunately, the Finno-Ugric youth was insignificantly represented at the forum exploring these issues. Nevertheless, performances, statements and reflections about the life and problems of young Finno-Ugrians, their present and future were tackled. I have touched upon the congress here only because the formulation of its main theme is largely connected to the topic of the present report.

Without youth there is no future. Also there will be no future for a language without youth speaking it. Any language without a younger generation of speakers is doomed. It is not a secret that many Finno-Ugric languages are in danger of disappearing (see UNESCO Atlas 2009; Report 2006). In the current demographic situation in which less and less children are speaking FinnoUgric languages this is a likely prospect and at present threatens a number of peoples, including Komi.

Any sphere of functioning of a language is extremely important for a highlevel development of this language. Restrictions of the use of language (for example, its use only in folklore) and its devolution to "kitchen language", or the language of peasants, leads to reducing its social status, and this, in turn, entails also a decrease in the status of its speakers. Each sphere where language falls out of active use is a step on the road to perdition (about domains of language use see also Vakhtin 2001: 204-206). In the light of the facts above, 
it is possible to claim that these spheres of the functioning language, where language users are mostly the younger generation, are vital for the existence of this language.

\section{KOMI TELEVISION, RADIO AND WRITTEN PRESS}

Within the framework of the topic, the printed and audio-visual functions of the language will be discussed. The Komi language is not in general demand in publishing, television and radio broadcasting, cinematography, showbusiness, virtual space, etc. While discussing the most recent, "advanced" and from the viewpoint of collective identity, the most dangerous phenomena of modern culture which have had the most favourable impact on a language, ${ }^{1}$ I have intentionally neglected the issue of national education, Komi theatre, the activity of folklore ensembles, and so forth. While their role leaves much to be desired, this does not mean that their value and role in the preservation, development, and popularisation of Komi language is secondary.

Publishing and the written press in the Komi Republic can be characterised as one with a poor variety and scanty circulation. Prose is limited to novels about rural life, historical characters, etc., and has virtually neglected urban culture. Also, no erotic prose, detective or science-fiction novels have been published in Komi language. On a positive note, a competition for the creative Finno-Ugric youth for the search of a work of this kind that has had the most favourable influence on the native language was held on the initiative of MAFUN, the Youth Association of Finno-Ugric Peoples. The competition was a success, though only some languages were presented. While emphasising these literary genres, I have no intention of understating the importance of serious literature in the development of an individual. To the contrary, it is vital to make the works of classic authors available in the Komi language. The publication of books in the Komi language is limited to a few dozen titles per year.

As to periodicals in the Komi language, the following figures should speak for themselves: in 1990, the number of Komi-language newspapers was 4, and in 2002 it was 5. By contrast, the number of Russian-language newspapers in the Komi Republic was 31 in 1990 and 95 in 2002. In 2002, only three magazines were published in the native language in the Komi Republic, with periodicals in Komi language constituting only 7.2 per cent of the total number of publications (110). (Tsypanov 2003: 35) 
According to the official data of the Ministry of Culture and Internal Affairs of the Komi Republic, the average airing time of Komi-language material on the radio station Komi gor ('The Voice of Komi') was only 6.33 hours per week (this percentage has remained invariable in the past few years), whereas half of the time (3.17 hours) was occupied by news, 1.66 hours of broadcasts of the programme on music and art, and 1.5 hours of public, analytical, and political programmes. $^{2}$

Komi-language television is broadcasted by two companies in the Komi Republic, but the airing of native language is also highly limited. In 2003, Komi gor prognosed to Komi language 5.7 hours of airing per week, including 2.5 hours of news transfer, 1.9 hours of covering public issues, 0.7 hours of education, 0.4 hours of sports coverages, 0.2 hours of children's programmes and entertainment. The Komi National Television Channel (KRTK - Komi respublikanskii televizionnyi kanal) prognosed only 0.66 hours of native language programmes per week. It only broadcasts native language programmes, mainly news, and anything else outside prime time.

On a positive note, a Komi-language talkshow was aired in 2004, which participants discussed political news of the republic, and which was the first Republican programme ever aired (Sokolov 2004).

Presently, a music programme Lad ('Tonality') about and targeted at musicians is running on KRTK. The programme lasts for about 15 minutes and is aired in two languages - Komi and Russian. The show has been aired for two years since January 2005, and has resulted in about 70 programmes (KRTK 2007).

\section{“ELEMENTS OF PROGRESS” IN ENHANCING THE STATUS OF KOMI LANGUAGE}

The influence of mass culture on indigenous youth is immense. The results of processes undergoing in collective consciousness under the influence of modern and, in particular, pop culture, unfortunately do not speak in favour of the development of national consciousness and preservation of the indigenous language. A study carried out among urban and rural youth by scholars at the Komi Science Centre has pointed out some reasons behind the fall in the prestige and status of the Komi language in the minds of the young generation and reveals how Komi youth shift from the Komi language to Russian in daily interaction (Bazhenova 2004; Likhacheva 2005). According to the report by Nadezhda Bazhenova on the 4th World Congress of Finno-Ugric Peoples, 
For the majority of young people, the Komi language is "the village language", the language which was spoken "in olden days". This means that the Komi language is actually not considered prestigious. At the same time, Russian is considered more prestigious by the young people, as it is the language of television, science, newspapers and magazines, the language of cinema and popular songs. All this symbolises progress for the young Komi. To speak the Komi language means to recognise oneself as backward and incompatible with modern life. (Bazhenova 2004)

The prestige is one of the factors causing the language shift. However, according to Nikolay Vakhtin, the low prestige of language itself does not call for a language shift: the reason why it has occurred is that language needs to strongly conform to the social, economic or other status of the group speaking it (Vakhtin 2001: 227-228).

The situation is aggravated by the escalating tendency of the migration of youth from rural areas, where there still is sufficient ground and a favourable environment for the developing of the Komi language, to cities to study at higher education schools, etc. ${ }^{3}$ In rural areas the Komi are still in the majority, ${ }^{4}$ but the economic importance of rural areas is constantly decreasing and large-scale departure from the villages continues. A Komi village is socially even more backward and that is why young people do not want to stay in the country but migrate to the cities with the Russian cultural and language environment.

The youth who move to the cities do not believe in the development of culture or the native language, or do not find it important, and equal the language of their ancestors with an outdated way of life. City culture is perceived as the standard, having the acceptable level of culture, while everything connected with village (which is equalled with Komi) is regarded as something backward (which represents a scornful attitude towards village life) and not to be practiced.

All the abovesaid leads to the conclusion that the so-called "elements of progress" like television, mass media, cinema, Internet, pop music etc., which from the perspective of the youth are part of the prestigious urban life, need to be Komified. While Internet is not always accessible for the Komi youth, because (at the present time) they live mainly in the villages, music in the Komi language is still spread over the radio and television, and recorded music and videos are available in the Komi language and can significantly affect the cultural situation. Popular songs and various websites in Komi language could motivate a change in the attitude towards the Komi language so that it would 
turn to signify a language of "progress". This also applies to other Finno-Ugric areas.

It is necessary to expand the sphere of application of Finno-Ugric languages more actively through the means of modern technologies (see also Likhacheva 2004, 2005). Today, computer and Internet access has become a necessity rather than a social habit or status symbol. Children acquire computer skills at an early age. Today, good computer skills are considered prestigious among the indigenous youth, and not only because computer and Internet access are one of "the elements of progress", but also by virtue of perspectives of information technological industry.

It seems impossible to claim that pop music and Internet use are only associated with youth, as both are changing phenomena of modern culture (pop music mainly because of "seasonal preference" or fashion, and the Internet due to rapid advances in information technology). Nevertheless, to a greater or lesser extent it is still, more likely, the "prerogative" of the younger generation. First, because youth are "centrifugal" in the behaviour: the young welcome innovations, they are more prone to adopt new things, which is in contrast with "centripetal" older people who are less inclined to changes (Vakhtin 2001: 237), also more radical and susceptible to everything new; second, the music which was considered pop music by yesterday's youth, has become outdated for today's, etc. The majority of Internet users in Russia are still the younger generation.

The problem with limited Internet access is resolved, as within the framework of modernising the educational system in the Komi Republic, supplying of schools with computers is being carried out. Accordingly, all schools will be eventually modernised and supplied with Internet access. ${ }^{5}$ For the general public, Internet access will be organised in post offices which are distributed over the entire territory of the republic. In principle, steps have been taken in this direction (see Repina 2007).

The attitude of Komi to their ethnic language and culture requires modernisation. The Komi need to stop viewing their culture and language as second-rate, underdeveloped in relation to culture and language of the Russians and other dominant cultures. This concerns also the people. Very few Komi would express this attitude, but for some reason I share the general impression that the majority of Komi would be doubtful whether rock or rap music can be created in the Komi language and do not question whether there is a need for that. Many would see the idea of organising a Komi disco as ridiculous. It is the stereotypical attitude of the Komi towards themselves and their language, which has partly developed over the course of history under external influences, and partly by virtue of their own nature. Therefore it is the 
Komi themselves that need to change. Komi-language pop music and other phenomena of modern culture as prestigious "elements of progress" from the point of view of the young Komi (Bazhenova 2004) could play a huge role in the popularisation and increasing of the prestige of the Komi language.

It is hardly possible to organise a more or less modern disco with the use of only Komi songs because there simply are not enough of these. Of course, one cannot claim that pop music and other types of music in Komi language do not exist, because they do. There are professionals and fans that create Komi music and try to promote entertainment in the Komi language. The number of modern songs in the Komi language is so small that they can be counted on fingers. Also, they cannot be considered popular as they do not reach the target audience: they exist but by now very few know about them. Komi pop music should be promoted to stimulate its creation, but who would be interested in it, except for patriots, fans, individuals and collectives directly involved in the indigenous culture and making the music?

From the aspect of collective identity, the most efficient way to distribute and popularise Komi pop, rock and other kind of music, would be the radio. The Komi national radio, which was established in 2007, broadcasts music, though the focus is on folklore motifs and melodies such as Kadysheva ${ }^{6}$ in the Russian music world, and there is not enough modern music for the youth. As to the distribution of Komi music, according to the Ministry of Culture and Internal Affairs of the Komi Republic, only one cassette of music was released in 2,000 copies and one compact disc was released in 1,000 copies in 2003.

In the most recent years $\mathrm{CDs}$ of Komi music have no longer been produced and have not been on sale. The reason for it might be that albums with Komi music are released on the order of the Ministry of Culture, which controls the entire release and does not put them on sale.

\section{ON A POSITIVE NOTE}

The last years have seen an increased releasing of music albums with songs in the Komi language. About a twenty or so CDs with Komi music have been published with the support of the Ministry of Internal Affairs. Almost all these albums make references to folk music, featuring national songs or author songs in folk style.

There are some albums of Komi songs which can be called more or less modern. The works of the famous Komi cultural figure Mikhail Burdin and Zarni an' ('The Gold Woman'), the group he supervises, are very interesting. Mikhail Burdin, who is a musician and composer and plays professionally sev- 
eral folk instruments, tries to merge traditional and modern music. In his compositions the vocals and folk instruments sound on the background of electronic music. Their latest albums (released in 2004 and 2008) feature ten arrangements of Komi folk songs. Some of the older recordings of songs on Eugeni Kozlov's verses in the collection So $i$ vois ar... ('Autumn Has Come') remain topical in the context of the insignificant number of songs of modern music available in the Komi language. In 2006, a new CD with songs on Eugeni Kozlov's verses was released. The album is called Jenezhva ('Heavenly Water') and is notable for its high sound quality. Among other things, the album is exceptional with its composition in country style. Perhaps the most successful album of modern Komi songs was released in 2000 as a Pavel Kochanov's project, the former general director of news agency "Komiinform". Songs from the album are available online at http://www.finugor.ru/?q=audio. There are some other musical arrangements by various Komi artists, for example, songs by Alexandr Chuvyurov, Alexandr Shebyrev, Grigory Ignatov, which have been incorporated in other albums of various genres, but this is more or less all.

Concerts and festivals of modern music would provide inspiration and creative support for groups who are able to create not only Komi folk songs, but also other type of music, as when there is no demand, there can be no supply. I might be mistaken, but to my knowledge no pop music concerts have been organised in the past few years. Festivals of Komi songs, where folklore motifs and melodies dominate, are carried out regularly: such is, for example, Vasiley (Vasily) Festival, where modern music is performed alongside folk creations, though even these are performed with "an accordion, bayan and balalaika" and there is no (electric guitar, etc.) music for youth. As is the case with literature, it has to be remembered that modern music should not be regarded as ranking higher than folk music, as these are incomparable, but the (potential) role of modern styles in enhancing the status of language is definitely underestimated.

On "Sosnogorsk 2004", the 12th national festival of jazz, rock and popular music, some Komi language songs entered the song contest for the first time (Arteev 2004). And while the soloist of Provocation, who does not speak the Komi language, gave a poor performance of a Komi song, his colleague Dasha Nosova, vocalist of ensemble Spectrum from Izhma, who performed a song "Beautiful girl from Izhma", won praise from audience and judges alike. Chairman of the festival jury, composer Mikhail Gertsman noted, "Fortunately, the color, at last, has appeared in Sosnogorsk. Even a tinge of folkness makes the music original".

Most recently, in January 2007 the show entitled Iz'vasa kodzuvjas ('The Stars of Izhma') took place in Izhma. ${ }^{8}$ The majority of songs were performed in 
Komi language and in modern arrangement, and a group of boys from the Vertep village also performed Komi rap, which sounds very similar to the music of the dances of tundra shamans (Tribune 2007).

Positive tendencies can be observed not only in the releasing of audio CDs with Komi music, but also about other multimedia projects in the Komi language. In 2006, a karaoke CD with popular Komi songs was released: the album includes the most popular folk and author songs with folk motifs and melodies, but does not feature pop music. In the past few years, some other CDs and DVDs have been released in Komi language: a CD of Komi fairy tales (2008), two computer games for children (2006 and 2009), Komi language-learning CD-ROM for beginners (2008), a double CD featuring audio language guide into Komi language Cholöm (2007), and Viktor Savin's radio performance "The Restless Soul", recorded in 1958-1959 (2007).

\section{CONCLUSION}

According to the report by Bazhenova (2004), ethnographer Nikolay Konakov, on his 1985 expedition to the Kola Peninsula ${ }^{9}$, showed his Komi informants in Krasnoshchel'e village, Lovozero District of Murmansk area, a newspaper. It was the first Komi-language newspaper that the local residents had ever seen. The newspaper attracted huge interest; people read the paper in groups, and many inquired about subscription. Finally, the newspaper was shown to a fellow Russian villager. Upon this, one of the informants declared with obvious pride, "Look! We also have newspapers printed in our language!", and another added, referring to Konakov, "And he has said that people even speak in our language on television!" Konakov has later noted that the newspaper that he brought to the Komi of Krasnoshchel'e has undone the ten years of assimilation of the locals. This appears to be a fine example of the efficiency of "the elements of progress" in increasing the status of the Komi language.

The establishment of music groups, procuring modern technical equipment, promoting their activity and creativity on the radio and television, the organisation of concerts, festivals and competitions, establishing and maintenance of Komi language websites and the linking of other "elements of progress" to the activisation and spread of the Komi language in the corresponding spheres require financial resources. This remains out of reach only for an insignificant number of individuals. Certainly, sponsoring these activities is important, and state financing to implement the corresponding policy to develop ethnic languages should not be the last resort. 
The creation and application of a new information technology in the use of the Komi language, support to children's and youth projects, and interaction with mass media are the priority of the target programme on the preservation and development of ethnic languages of the Ministry of Internal Affairs (Finnougoria 2008). Indeed, some projects and products of their realisation are quite praiseworthy (the release of $\mathrm{CDs}$, etc.) but according to the legislation the state, who has ordered these, has to send all the copies to libraries and schools, and so there are no books and CDs available for purchase. Therefore, new books and electronic works are inaccessible for the general public (Finnougoria 2008).

Unfortunately, in the past five years there has not been an increase in the prestige and demand of the Komi language or spread of its use. Quite the contrary, the use of the Komi language has decreased. However, the hope remains that the realisation of already the fifth programme on the preservation and development of the Komi language will bear fruit in the long term.

\section{NOTES}

1 As to the role of mass media in language preservation, there is also an opinion that television has no considerable influence on language (Chambers 1998: 124, 125 after Vakhtin 2001: 202).

2 This data requires updating because substantial changes have taken place in Komi broadcasting by the time this article was submitted to publication. In November 2007 , the new Komi national radio has started broadcasting. Today this radio broadcasts 12 hours per day, and can be listened on the Internet (available at mms:// 217.24.112.58:8100/).

3 Urbanisation as one of the factors causing language shift is also important; for example in the case of the languages of the small peoples of the Russian North (Vakhtin 2001: 225-226).

${ }^{4}$ According to the 2002 census in Komi Republic, 56 per cent of the rural population (ca. 246,000 inhabitants) are Komi (ca. 138,000), and a share of the rural population makes up 53.8 per cent of the total number of Komi (ca. 256,500). Cf. only 15.3 per cent of Russians in the Komi Republic live in villages. At the same time, the cities in the Komi Republic look quite similar to Russian cities (Statistics 2005: 30; Census 2002).

5 Already in 1995, the Minister of Education of the Komi Republic said that he would like to see the schools given Internet access soon (Habeck 1998: 280, 285).

6 The wellknown Russian singer who performs songs in the style of Russian folk songs.

${ }^{7}$ Bayan is a type of accordion and balalaika is a Russian stringed musical instrument, both are associated with folk music. 
${ }^{8}$ Izhma is a district in the northern part of the Republic of Komi.

9 There is a small Komi diaspora (around 1,500) among the Sámi population on the Kola Peninsula. They are the descendants of the reindeer-breeders who have removed there from Izhma at the end of the 19th century.

\section{REFERENCES}

Arteev, Artur 2004. Rokovye dni v Sosnogorske. [Days of Rock in Sosnogorsk.] Available at http://www.kominarod.ru/gazeta/papers/paper_152.html, last accessed on 1 March 2009.

Bazhenova, Nadezhda 2004. Proekt "Elektronnaia biblioteka na finno-ugorskikh iazykakh". Doklad na sektsii SMI i informatsionnye sistemy na IV Vsemirnom kongresse finno-ugorskikh narodov (Tallinn, 15-19 avgusta 2004 g.). [Project "Electronic Library in Finno-Ugric Languages". Report on sections of massmedia and information systems on the 4th World Congress of the Finno-Ugric people (Tallinn, 15-19 August 2004).] Available at http://www.finugor.ru/news/ sob/kon_bazhenova.doc, last accessed on 1 October 2004.

Census 2002 = Vserossiiskaia perepis' naseleniia 2002 goda. [2002 National Census in Russia.] Available at http://www.perepis2002.ru/index.html?id=11, last accessed on 1 March 2009.

Finnougoria 2008 = Eugeni Rozhkin: "Innovatsii pomogaiut sokhranyat' komi iazyk". [Eugeni Rozhkin: "Innovations help to keep Komi language".] Finnougoria. Ethnic comfort 4. Available at http://www.finnougoria.ru/periodika/index.php? ELEMENT_ID=9219, last accessed on 1 March 2009.

Habeck, Joachim Otto 1998. The Existing and Potential Role of the Internet for Indigenous Communities in the Russian Federation. In: E. Kasten (ed.) Bicultural Education in the North: Ways of Preserving and Enhancing Indigenous Peoples' Languages and Traditional Knowledge. Münster, New York, München, Berlin: Waxmann.

KRTK 2007 = Komi respublikanskii televizionnyi kanal. [The Komi National Television Channel.] Available at http://www.krtk.ru/home.php, last accessed on 1 March 2009.

Likhacheva, Natalia 2004. Sferu primeneniia finno-ugorskikh iazykov planiruetsia rasshiriat's pomoshch'iu sovremennykh tekhnologii. [Plans to Expand the Sphere of Application of Finno-Ugric Languages by Means of Modern Technology.] Komiinform. Available at http://www.komiinform.ru/index.php?in=25568\&curdate $=1.6 .2004$, last accessed on 1 July 2004 .

Likhacheva, Natalia 2005. Sovremennye tekhnologii sposobny podniat' status rodnogo iazyka sredi molodezhi, schitaiut spetsialisty Komi. [Experts of Komi Language Agree, "Modern Technologies Can Enhance the Status of a Native Language Among Youth".] Komiinform. Available at http://www.komiinform.ru/ index.php?in $=33280 \&$ curdate $=16.11 .2005$, last accessed on 16 November 2005 .

Repina, Olga 2007. V Komi v 2007 godu poiavitsia 95 novykh punktov kollektivnogo dostupa k seti Internet. [95 New Points of Public Internet Access in Komi in 
2007.] Komiinform. Available at http://www.komiinform.ru/?id=27993\&in= 40004\&curdate $=17.1 .2007$, last accessed on 17 January 2007.

Report 2006 = Situation of Finno-Ugric and Samoyed Peoples. Report in the Committee on Culture, Science and Education, San Marino. Doc. 11087. Council of Europe Parliamentary Assembly. Available at http://assembly.coe.int/Main.asp?link= /Documents/WorkingDocs/Doc06/EDOC11087.htm, last accessed in March 2009.

Sokolov, Igor 2004. V nastupaiushchem sezone Komi respublikanskii telekanal vozrozhdaet starye proekty i zapuskaet novye. [In a Coming Season the Komi Republican Television Channel Revives Old Projects and Starts New Ones.] Komiinform. Available at http://www.komiinform.ru/index.php?in=26891\&curdate=8.9.2004, last accessed on 8 September 2004.

Statistics 2005 = Finno-Ugric and Samoyed Peoples in Russia. Statistical handbook. Syktyvkar.

Tribune 2007 = Mal'chiki iz Vertepa pokazali rep. [Boys from the Vertep Performed Rap.] - Tribune (26 January 2007). Available at http://www.tribuna.nad.ru/modules/news/article.php?storyid=3336, last accessed on 29 January 2007.

Tsypanov, Eugeni 2003. Gosudarstvennyi li komi iazyk s tochki zrenia ego funktsionirovania. [Whether the Komi Language is an Official Language from the Perspective of Its Functioning.] In: Problemy i perspektivy razvitiia vostochnykh finno-ugorskikh iazykov: Materialy nauchno-prakticheskoi konferentsii "Funktsionirovanie iazykov $i$ sostoianie etnokul'tury vostochnykh finno-ugorskikh narodov: problemy i perspektivy razvitiia" (4-7 iiun'a 2003 g., Saransk). [Problems and Prospects of Development of East Finno-Ugric Languages: Materials of Scientific-Practical Conference "Functioning of Languages and a Condition of Ethnoculture of East Finno-Ugric People: Problems and Development Prospects" (on June 4-7 2003, Saransk).] Saransk: Krasnyi Oktiabr', pp. 31-40.

UNESCO Atlas 2009 = UNESCO Atlas of the World's Languages in Danger. Available at http://www.unesco.org/culture/ich/index.php?lg=EN\&pg=00139, last accessed on 1 March 2009.

Use of language $=$ Svedeniia ob ispol'zovanii komi iazyka 2000-2003. Ofitsial'nye dannye Ministerstva kul'tury i natsional'noi politiki Respubliki Komi. [Data of the Use of Komi Language in 2000-2003. Official Information of Ministries of Culture and Internal Affairs of the Komi Republic.]

Vakhtin, Nikolai 2001. Iazyki narodov Severa v XX veke. Ocherki iazykovogo sdviga. [Languages of the People of the North in the 20th century. Overview of the Language Shift.] Sankt-Peterburg: Dmitrii Bulanin. 